\title{
SHELL GROWTH IN THE SCALLOP ARGOPECTEN IRRADIANS. I. ISOTOPE INCORPORATION WITH REFERENCE TO DIURNAL GROWTH
}

\section{ALFRED P. WHEELER, PATRICIA L. BLACKWELDER, ${ }^{1}$ AND KARL M. WILBUR Department of Zoology, Duke University, Durham, North Carolina 27706}

Many molluses have markings in their shells indicative of periodic incremental growth, and in some species the markings are known to be formed daily (see Rhoads and Pannella, 1970; Wilbur, 1972). Periodic shell growth presumes accompanying physiological and biochemical changes relating to protein synthesis, secretion, and calcium transport since these processes are a part of shell formation. Such periodic changes have not been characterized. However, rhythmic changes in the general metabolism of molluscs have been reported (Sandeen, Stephens and Brown, 1954; Brown, Bennett, Webb and Ralph, 1956; Wright, 1971). Environmental factors which may be involved in periodic growth patterns such as photoperiod (House and Farrow, 1968; Wrenn, 1972) would be expected to trigger biochemical events or to change reaction rates.

The incremental nature of growth is strikingly clear in the shells of scallops in which there is a daily pattern of horizontal shell extension and ridge formation (Clark, 1968; this paper, Fig. 4). The horizontal portion is deposited by the mantle when it is extended horizontally, and the ridge is produced by deposition during a period when the mantle edge is curved upward (Wrenn, 1972; Clark, 1974). Because of the diurnal nature of shell deposition in Argopecten irradians and the clear differences in the shell pattern within each daily cycle, this bivalve provides excellent opportunities for the investigation of physiological aspects of shell formation.

The objective of the present study is the measurement of calcium carbonate deposition during periodic daily growth of the scallop $A$. irradians employing ${ }^{45} \mathrm{Ca}$ and ${ }^{14} \mathrm{C}$-bicarbonate. However, we first examined the adequacy of the isotope method in providing a reliable measure of mineralization during short periods. Attention has been given to (1) the rate of attainment of a steady state between radioisotopes in the medium and the shell-forming mantle tissue, (2) isotope incorporation into shell as a linear function of time, (3) exchange between shell and medium, (4) correlation between size of animals and rates of isotope incorporation into shell, and (5) deposition rates in various shell regions. The results have permitted us to define conditions under which isotopes can be employed to measure shell growth and to investigate diurnal variations in mineral deposition.

\section{Materials and Methods}

\section{Maintenance of animals}

Specimens of $A$. irradians were collected by hand during the summer in the Beaufort, North Carolina region. The animals were maintained in tanks with

${ }^{1}$ Present address: Electron Microscope Laboratory, University of South Carolina, Columbia, South Carolina 29208. 
running sea water at $23-25^{\circ}$ C. Natural illumination was supplemented with fluorescent lighting during the day. Under these conditions, the scallops grew and formed daily ridges. Some animals were transported to Durham, North Carolina where they were kept in recirculating sea water at $16-18^{\circ} \mathrm{C}$ under constant fluorescent light. They were fed by constant flow from a mixed culture of diatoms and algae. Periodic examination of the digestive tract of sacrificed individuals indicated that the animals were feeding. These animals did not increase in linear dimensions, nor did they form daily ridges.

\section{Exposure of animals to radioisotopes}

For the radioisotope studies, three animals were maintained in one liter of aerated sea water in a large fingerbowl at $23-25^{\circ} \mathrm{C}$ for approximately 1 hour. Animals displaying swimming behavior were replaced by other animals. Ten to $50 \mu \mathrm{Ci}$ $\mathrm{NaH}^{14} \mathrm{CO}_{3}\left(698 \mu \mathrm{Ci} / \mathrm{mg}\right.$, Amersham Searle) and/or ${ }^{45} \mathrm{CaCl}_{2}(13.0 \mu \mathrm{Ci} / \mathrm{mg}$, New England Nuclear) in $0.10 \mathrm{ml}$ were then added to the sea water containing the animals. At the termination of exposure to the radioisotopes, the shells were removed and cleaned of tissue, rinsed thoroughly with tap water, dried overnight at room temperature, and weighed. Empty shells were exposed to isotopes under the same conditions as for the living animals.

In light-dark experiments, animals were placed in one 1 aerated sea water approximately 1.3 meters from two 40 -watt fluorescent lamps covered by a frosted plastic sheet. Other animals were placed in one liter of aerated sea water in containers covered to exclude light.

\section{Radioisotope measurements of shell}

${ }^{14} \mathrm{C}$-carbonate incorporated into the shell was measured by cutting pieces from the right valves with a high speed drill fitted with a saw bit. With the exception of the studies on incorporation rates in various shell regions (see Fig. 2), the pieces examined were cut from the ventral edge. They weighed $10 \mathrm{mg}$ to $30 \mathrm{mg}$ and were approximately $5 \mathrm{~mm}$ in the dimension perpendicular to the shell edge and included 3-5 $\mathrm{mm}$ of the shell edge. Pieces cut from other regions also weighed $10 \mathrm{mg}$ to $30 \mathrm{mg}$ but the dimensions varied depending on the region studied. The pieces were placed in 10-ml flasks with rubber serum stoppers from which plastic center wells (Kontes Glass) were suspended (Speeg and Campbell, 1968). The center wells were filled with $0.4 \mathrm{ml}$ of $1 \mathrm{~N}$ hydroxide of hyamine in methanol (Packard), and the stopper was carefully inserted in the flask. Two $\mathrm{ml} \mathrm{5 \%}$ trichloroacetic acid (TCA) were injected through serum stopper to dissolve the calcium carbonate of the shell and liberate $\mathrm{CO}_{2}$ which was then trapped by the hydroxide of hyamine. It was calculated that $0.4 \mathrm{ml}$ of $1 \mathrm{~N}$ hydroxide of hyamine was sufficient to absorb all the $\mathrm{CO}_{2}$ liberated from the shell samples. After allowing about one hour for the absorption of $\mathrm{CO}_{2}$ by the hydroxide of hyamine, the center wells were placed in $10 \mathrm{ml}$ scintillation fluid containing $4.0 \mathrm{~g}$ PPO and 50 mgs POPOP per liter of toulene. Samples were counted in a liquid scintillation counter after storage in the dark to reduce fluorescence due to the hyamine solution. Isotope measurements on 3 pieces of each shell were averaged. 
If the animals had been incubated in both ${ }^{45} \mathrm{Ca}$ and ${ }^{14} \mathrm{C}$-bicarbonate, the ${ }^{45} \mathrm{Ca}$ was recovered by drying the dissolved shell residue in the bottom of the flasks at $70^{\circ} \mathrm{C}$, redissolving the residue in $2 \mathrm{ml} 100 \%$ ethanol, and adding the ethanol to $10 \mathrm{ml}$ scintillation fluid. Small variations in the amount of ethanol or variations of calcium salt of the magnitude present in the samples did not affect counting efficiency. The molar amount of calcium and carbonate incorporated into shell was calculated according to Wilbur and Jodrey (1952) assuming a concentration in sea water of $2.5 \mathrm{~mm}$ bicarbonate and $9.5 \mathrm{~mm}$ calcium.

The proteinaceous component remaining after dissolution of the shell mineral was dissolved by warming in $0.5 \mathrm{ml}$ hydroxide of hyamine. The hydroxide of hyamine was then added to $10 \mathrm{ml}$ scintillation fluid and counted. The protein had negligible radioactivity and was not considered a source of error in interpreting the activity present in the mineral constituents.

The sea water medium was sampled throughout the course of experiments using the same methods for detection of the isotopes as used for shell. The specific activity did not vary by more than $10 \%$ during the course of a 5 -hour experiment.

\section{Radioisotope measurements of mantle}

Following exposure of animals to the radioisotopes, the right mantle was dissected, rinsed in tap water, and dried to constant weight at $70^{\circ} \mathrm{C}$. The mantle was then homogenized for two minutes in a motor-driven ground glass mortar and pestle with $2 \mathrm{ml} \mathrm{10 \%}$ TCA to liberate remaining ${ }^{14} \mathrm{C}$-bicarbonate and to solubilize the ${ }^{45} \mathrm{Ca}$. The volume was brought to $10 \mathrm{ml}$ with distilled water and the material centrifuged. The pellet was washed once with $5 \mathrm{ml}$ distilled water. One $\mathrm{ml}$ of both supernatants was added to $10 \mathrm{ml}$ Bray's solution (Bray, 1960) and the ${ }^{45} \mathrm{Ca}$ counted.

The TCA-precipitated pellet from the mantle was dried and prepared for counting as described for shell protein. Less than $5 \%$ of the extracted activity was associated with the protein after five hours incubation, indicating that essentially all the ${ }^{45} \mathrm{Ca}$ was dissolved and little ${ }^{14} \mathrm{C}$-bicarbonate remained in the acidified pellet as bicarbonate or was fixed into protein.

\section{Weight of shell protein}

In determining protein content of shell, pieces of shell were weighed and dissolved in 5\% TCA. The protein was centrifuged and the pellet was washed once in $5 \% \mathrm{TCA}$, once in $95 \%$ ethanol, and dried to constant weight at $70^{\circ} \mathrm{C}$. For measurements of the protein content of the daily shell ridges, the ridges were scraped from the shell with care to avoid damage to the shell surface proper. They were then treated in the same manner as the other pieces of shell.

\section{Scanning electron microscopy}

Pieces of shell taken from the edge were coated with gold-palladium, mounted on aluminum stubs coated with silver paint, and examined by scanning electron microscopy. 

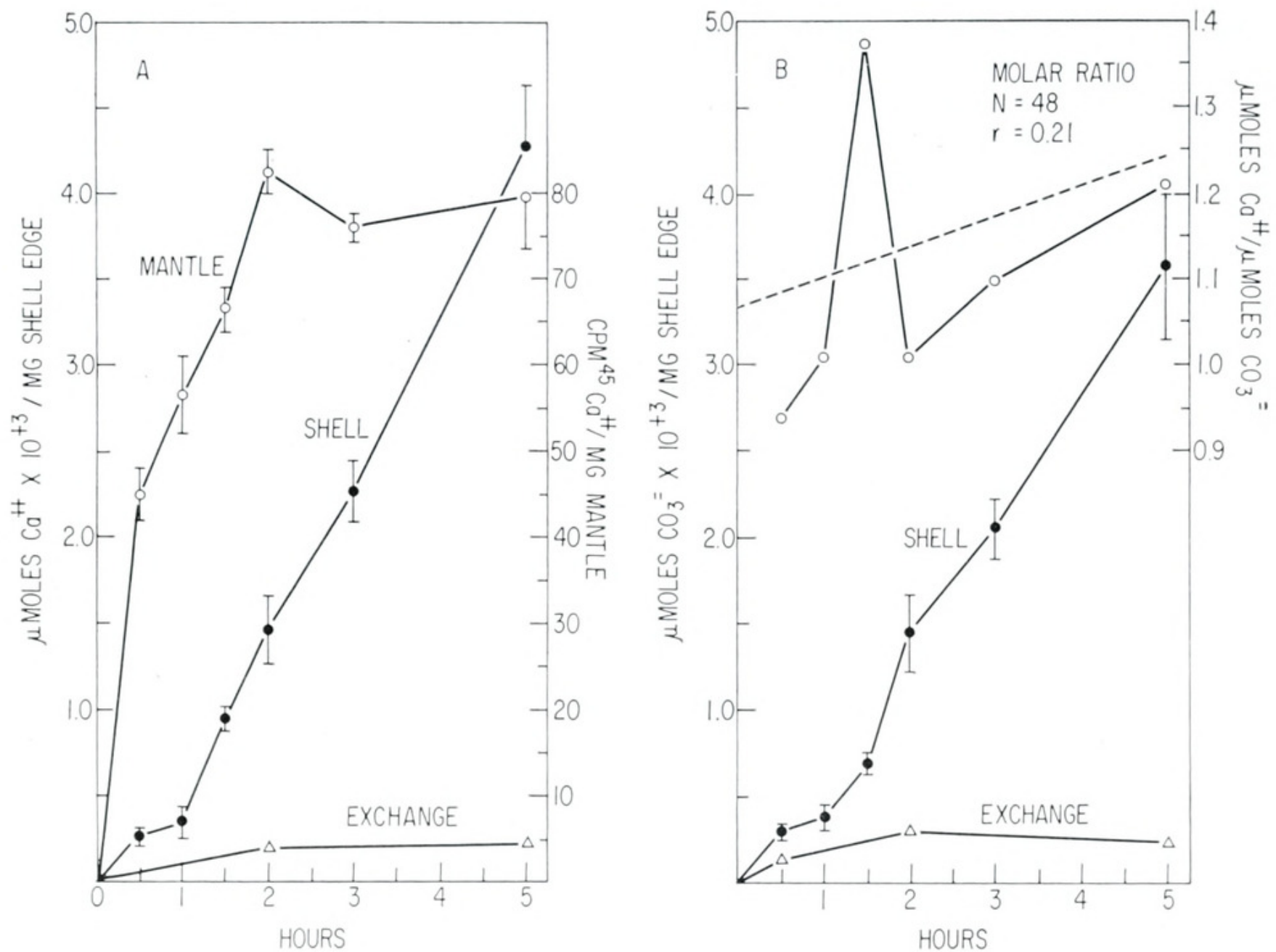

Figure 1. (A) Rate of ${ }^{45} \mathrm{Ca}$ incorporation into the right valve, ventral edge (closed circles); and the rate of ${ }^{45} \mathrm{Ca}$ saturation by the right half of the mantle (open circles). Each point represents the mean incorporation for eight animals. The vertical limits indicate standard deviations of the mean. For rate of shell incorporation, triplicate pieces were cut from the ventral edge of each valve, counted, and the results averaged. Exchange of calcium in empty shells is also shown (triangles). The medium contained $6.06 \times 10^{4} \mathrm{cpm} / \mathrm{ml}{ }^{45} \mathrm{Ca}$. (B) Rate of carbonate incorporation into the right valve (closed circles); the mean molar ratio of calcium:carbonate at the time intervals indicated (open circles); and the regression line for the molar ratio as a function of time calculated from the individual data points (dotted line). The carbonate incorporation values for each animal were obtained from the same triplicate pieces cut from the shells of the same eight animals as for calcium incorporation (Fig. 1A). The vertical limits indicate standard deviations of the mean. Exchange of carbonate in empty shells is also shown (triangles). The medium contained $2.17 \times 10^{4} \mathrm{cpm} / \mathrm{ml}{ }^{14} \mathrm{C}$-bicarbonate.

\section{Results}

Uptake of isotopes by mantle and shell

Figure $1 \mathrm{~A}$ shows the rate of uptake of ${ }^{45} \mathrm{Ca}$ in the mantle and ventral shell edge of animals maintained in running sea water. Uptake of ${ }^{45} \mathrm{Ca}$ in the mantle was rapid and a steady state with the medium was reached in two hours. Deposition of ${ }^{45} \mathrm{Ca}$ in the shell was linear after a lag of about 1 hour. Deposition of ${ }^{14} \mathrm{C}$ carbonate in shell followed a course similar to that for ${ }^{45} \mathrm{Ca}$ (Fig. 1B). The lag in the case of ${ }^{14} \mathrm{C}$-carbonate was about 2 hrs. For both isotopes, the exchange with empty shells was $5 \%$ to $8 \%$ of the total incorporation at five hours (Figs. 1A, B). 


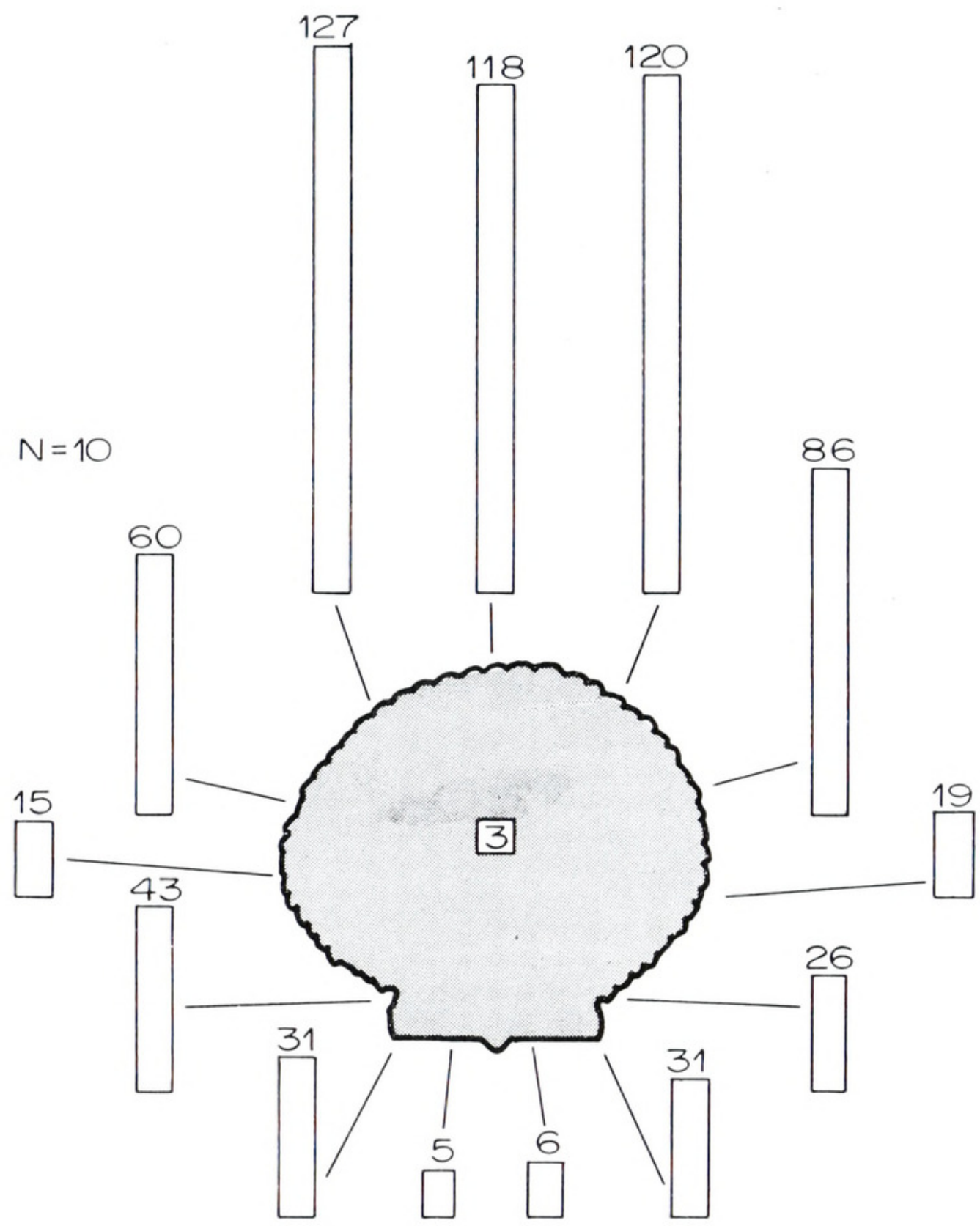

Figure 2. Incorporation of ${ }^{14} \mathrm{C}$-carbonate in regions of the shell. The values show the mean cpm per $\mathrm{mg}$ of shell sample for a 4-hour incubation for ten animals. The height of the bars is proportional to incorporation. The medium contained $20 \mu \mathrm{C} /{ }^{14} \mathrm{C}$-bicarbonate.

The calcium-to-carbonate molar uptake ratios for shell edge was determined from the mean values for each time interval indicated in Figures $1 \mathrm{~A}$ and $1 \mathrm{~B}$ and are shown in Figure 1B (upper curves). The mean incorporation ratio of all individuals tested was $1.5 \pm 0.24$ and was not significantly different from 1.00 even at the $50 \%$ level for a two-sided Student's t-test. Since a slight increase in molar ratio with time was indicated by the mean values at each point, a regression line of $\mathrm{Y}$ on $\mathrm{X}$ was calculated from all the individual data points by the method of least squares (Fig. 1B). The correlation coefficient for the plot of molar ratio against incubation time was very low $(0.21)$.

The rate of uptake of ${ }^{45} \mathrm{Ca}$ in mantle of animals maintained in a recirculating sea water tank in Durham, North Carolina was virtually identical with that of animals in running sea water at Beaufort, North Carolina. Incorporation of ${ }^{45} \mathrm{Ca}$ 
and ${ }^{14} \mathrm{C}$-carbonate into shell of animals in recirculating sea water followed a nearly linear course but at a lower rate. An abnormal chalky layer was noted on the inner shell surface near the edge of these animals. Examination of the abnormal layer by scanning electron microscopy indicated that the layer was due to deposition of material different from normal shell and that dissolution of normal shell layers adjoining the chalky deposit was not evident. This deposition may account for isotope incorporation since growth in area at the edge did not occur. Studies described in the following sections were all carried out with animals maintained in running sea water at Beaufort.

\section{Deposition rates in various shell regions}

The rate of incorporation of ${ }^{14} \mathrm{C}$-carbonate varied considerably in different regions of the shell. Figure 2 shows that the highest rates were at the ventral shell edge in the area of the longest ribs and that the lowest rates were in the central shell region and at the dorsal edge adjacent to the hinge. For making measurements of maximum sensitivity, the region of the ventral edge was selected for subsequent studies.

\section{Rate of deposition and shell weight}

The rate of deposition of ${ }^{45} \mathrm{Ca}$ and ${ }^{14} \mathrm{C}$-carbonate at the ventral shell edge as a function of valve weight for one experiment is given in Figure 3. There was a virtual absence of trend in deposition rate with size. The correlation coefficient calculated was -0.22 for ${ }^{14} \mathrm{C}$-carbonate and -0.13 for ${ }^{45} \mathrm{Ca}$. Other data on deposition rates of ${ }^{45} \mathrm{Ca}$ and ${ }^{14} \mathrm{C}$-carbonate over a range of weights from $2 \mathrm{~g}$ to $12 \mathrm{~g}$ gave the same low correlation. The total number of animals used for these experiments was 131.
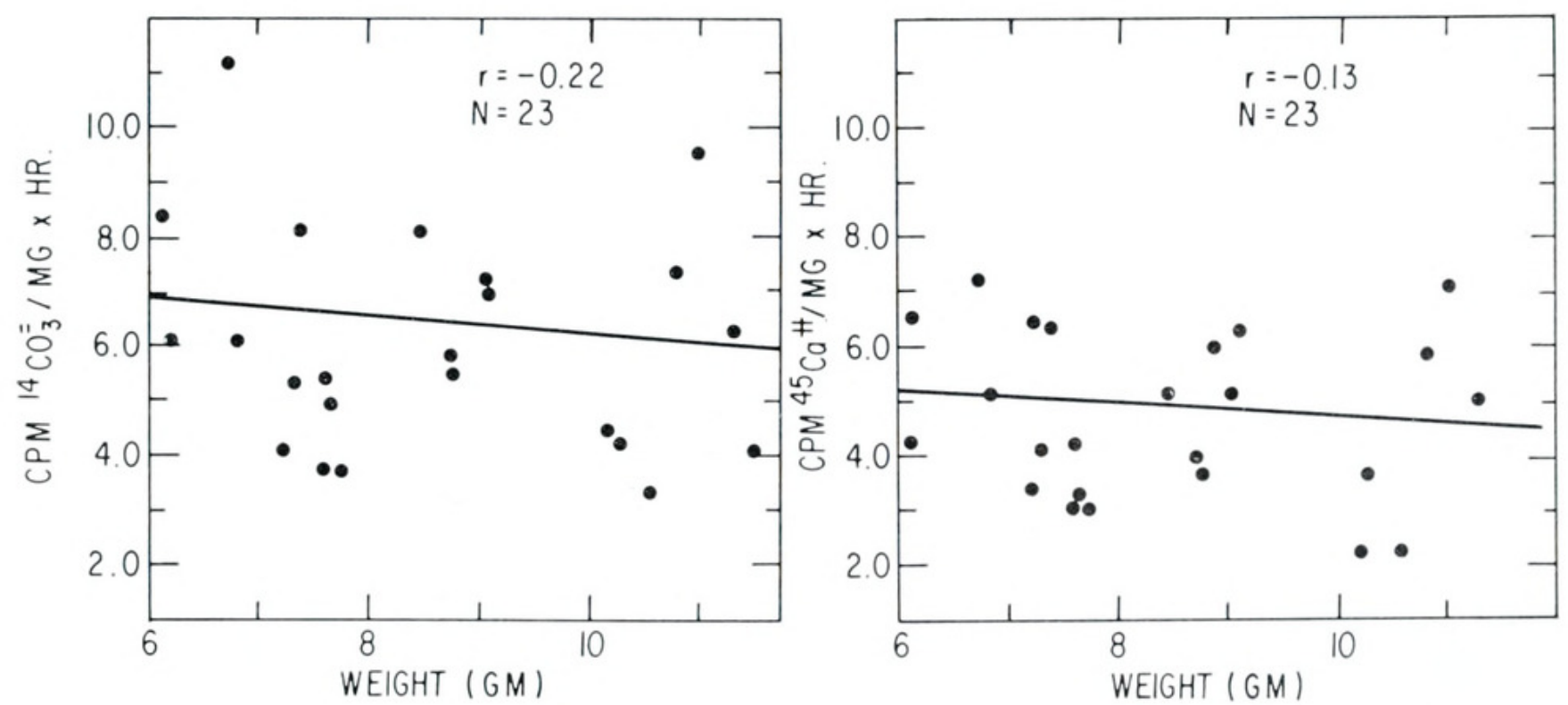

Figure 3. Rate of incorporation of ${ }^{14} \mathrm{C}$-carbonate and ${ }^{45} \mathrm{Ca}$ as a function of weight of the right valve. Each point represents the mean of triplicate pieces from the ventral edge of the shell of one animal. The regression lines were calculated by the method of least squares with $r$ being the correlation coefficient and $\mathrm{N}$, the number of animals. 
TABLE I

Diurnal mantle activity and calcification rates.

\begin{tabular}{|c|c|c|c|}
\hline & $10: 30 \mathrm{AM}-2: 30 \mathrm{PM}$ & \multicolumn{2}{|c|}{$6: 30$ PM- $8: 30$ PM } \\
\hline Minimum $\%$ upturned* & 8 & \multicolumn{2}{|r|}{83} \\
\hline & $\begin{array}{c}10: 00 \text { AM-2:00 PM } \\
\text { Light }\end{array}$ & $\begin{array}{c}10: 00 \text { AM-2:00 PM } \\
\text { Dark }\end{array}$ & $\begin{array}{c}7: 00 \text { PM- } 8: 30 \text { PMI } \\
\text { Dark }\end{array}$ \\
\hline $\begin{array}{l}\text { Calcification } \\
\text { cpm }{ }^{14} \mathrm{C} \text {-carbonate per } \mathrm{mg} \text { per hr }\end{array}$ & $\begin{aligned} 24.0 & \pm 3.0 \\
\mathrm{~N} & =17\end{aligned}$ & $\begin{aligned} 24.3 & \pm 3.2 \\
\mathrm{~N} & =25\end{aligned}$ & $\begin{aligned} 6.7 & \pm 1.3 \\
\mathrm{~N} & =26\end{aligned}$ \\
\hline
\end{tabular}

* Data from Wrenn (1972). Figures show minimum percentage of animals which turned mantles over the shell edge, forming vertical ridges.

\section{Diurnal deposition rates}

Shell growth increments in $A$. irradians, indicated by ridges that delineate a day's growth (Fig. 4), are formed by the upturning of the mantle over the shell edge (Wrenn, 1972; Clark, 1974). Wrenn has demonstrated that the ridges are formed primarily in late afternoon and evening (Table I).

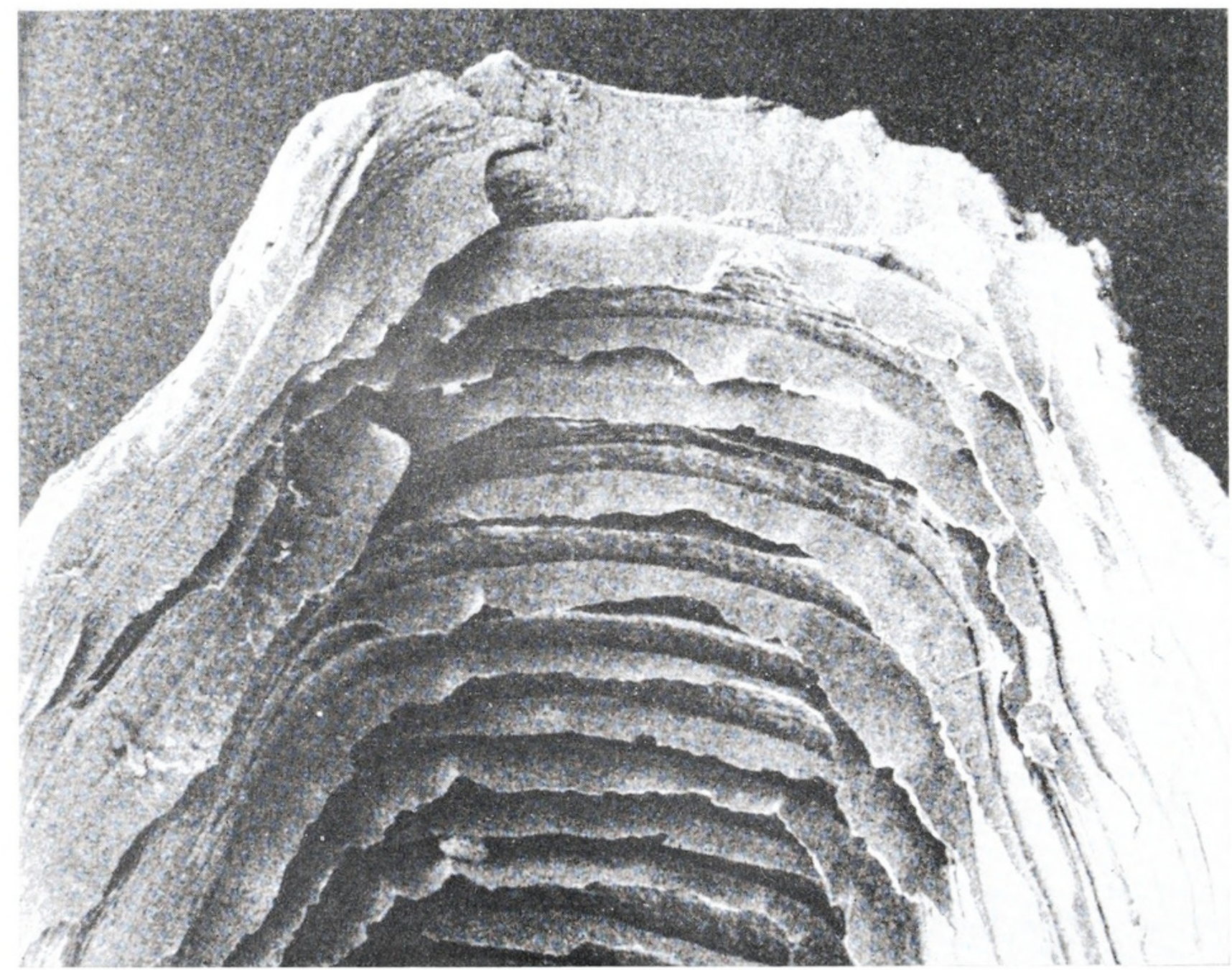

Figure 4. Scanning electron micrograph taken at the ventral edge of the right valve $(\times 30)$. Each vertically positioned ridge delineates one day's growth. 
The rate of incorporation of ${ }^{14} \mathrm{C}$-carbonate was measured during a period when little ridge formation was occurring and new interridge shell was being deposited (10 AM to $2 \mathrm{PM}$ ) and during a period when much ridge formation was taking place (7 PM to $8: 30 \mathrm{PM}$ ). The rate of ${ }^{14} \mathrm{C}$-carbonate deposition was more than 3 -fold greater when ridges were not being formed as compared with the period of their formation (Table I). The difference was significant at greater than the $99 \%$ level for the two-sided Student's t-test.

To test the effect of short-term periods of light and darkness on incorporation rates of ${ }^{14} \mathrm{C}$-carbonate, scallops were incubated in total darkness and light during the period 10 am to 2 PM. No significant difference between the two groups was found (Table I).

\section{Protein content of shell}

The protein content of the shell ridges was $32.9 \pm 3.9 \% \quad(\mathrm{~N}=3)$, and the protein content of shell including ridges was $16.0 \pm 2.1(\mathrm{~N}=3)$. The difference shows that the mineralization of the shell ridges is much less than the other portion of the shell. The average shell protein content of $16 \%$ is very high (Wilbur and Simkiss, 1968), probably reflecting in part the elevated protein content of the shell ridges.

\section{DISCUSSION}

The measurement of shell growth by means of radioisotopes, especially during short periods, requires that: (1) the shell-forming mantle tissue come into steady state with the medium rapidly (Wilbur and Jodrey, 1952); (2) that shell dissolution by metabolites be minimal as compared with calcium deposition (Crenshaw and Neff, 1969); and (3) that exchange between the shell and the extrapallial fluid in contact with the inner shell surface be at a low level as compared with calcium deposition.

The present study with Argopecten has demonstrated that the mantle reaches a steady state with ${ }^{45} \mathrm{Ca}$ of the sea water medium within two hours, a value nearly identical with that of the oyster Crassostrea virginica (Jodrey, 1953) and the oyster Crassostrea gigas (Kado, 1960). The relatively rapid rate of ${ }^{45} \mathrm{Ca}$ penetration and the resulting small lag in shell incorporation satisfies the steady state requirement for short-term measurements of shell growth with ${ }^{45} \mathrm{Ca}$. Since the calcium-to-carbonate molar ratio of incorporation is largely independent of time of incubation, the saturation of mantle for ${ }^{14} \mathrm{C}$-bicarbonate probably takes place at about the same rate as for ${ }^{45} \mathrm{Ca}$ and thus also satisfies the steady state requirement for measurement of short-term mineralization.

Wilbur and Jodrey (1955) suggested that metabolic $\mathrm{CO}_{2}$ may play an important role in shell carbonate formation in the oyster Crassostrea virginica. In Argopecten, bicarbonate entering directly from sea water rather than being derived from metabolic $\mathrm{CO}_{2}$ may be the main source of shell carbonate. This is indicated by a calcium-to-carbonate molar ratio of approximately unity throughout the 5 -hour period of exposure to ${ }^{45} \mathrm{Ca}$ and ${ }^{14} \mathrm{C}$-bicarbonate. If metabolic $\mathrm{CO}_{2}$ were important, then one would expect the ${ }^{45} \mathrm{Ca}$ - to ${ }^{14} \mathrm{C}$-carbonate ratio would be higher at the start of the experiment when little metabolizable substrate would be labelled and then decrease with time as ${ }^{14} \mathrm{C}$-bicarbonate labelled the substrates. However, if 
there were a rapid turnover in $\mathrm{CO}_{2}$ fixation in the mantle, bicarbonate from the medium could not be readily distinguished from bicarbonate originating from metabolic $\mathrm{CO}_{2}$. Hammen and Wilbur (1959) suggested for oyster mantle that pools of organic and amino acids with turnover times in the same range as suggested here for bicarbonate were available for $\mathrm{CO}_{2}$ fixation from a $\mathrm{H}^{14} \mathrm{CO}_{3}$-labelled medium. However, the relative sizes of pools of free bicarbonate and bicarbonate that had been fixed were not determined so an estimate of ther relative contribution to formation of shell carbonate cannot be made. In the absence of data, the relative contribution of bicarbonate from the medium and from metabolic sources must be left open.

The second requirement for the use of radioisotopes in shell growth studies, i.e., that shell dissolution due to organic acid accumulation be minimal, is not likely to be important for Argopecten since its valves are normally open and water is circulated over the mantle continuously. This behavior contrasts with that of the clam Mercenaria mercenaria studied by Dugal (1939) and Crenshaw and Neff (1969) in which there are periods of valve closure and absence of pumping during which organic acids accumulate in contact with the inner shell surface.

The third requirement, namely the low level of exchange between shell and the extrapallial fluid in contact with the inner shell surface, appears to be met even though exchange is not measurable in vivo. Exchange as measured in sea water with $\mathrm{H}^{14} \mathrm{CO}_{3}$, and ${ }^{45} \mathrm{Ca}$ in Argopecten was $5 \%$ to $8 \%$ of the total radioisotope incorporation measured at the shell edge at five hours. Exchange in vivo may well be lower than this since the amount of ${ }^{14} \mathrm{C}$-carbonate incorporated in the central region of the valve was less than $3 \%$ of that incorporated at the ventral edge (Fig. 2). An exchange rate considerably higher than that in sea water is unlikely in view of the similarity of the concentrations of calcium and carbonate in sea water and the extrapallial fluid of other bivalves (Crenshaw, 1972). A further consideration of the magnitude of exchange relative to net shell growth is the fact that Argopecten is forming shell very rapidly as indicated by the size of the daily growth increments.

Even though all the foregoing requirements are fulfilled, caution must still be exercised in interpreting isotope incorporation as a measure of normal growth. A case in point relates to specimens of Argopecten kept in a recirculating sea water tank rather than in running sea water. These animals deposited both ${ }^{45} \mathrm{Ca}$ and ${ }^{14} \mathrm{C}$-carbonate yet did not show linear shell growth, nor did they form daily ridges.

The rate of isotope incorporation in molluscan shells has been found to decrease with shell weight (Zischke, Watabe and Wilbur, 1970). However, in Argopecten the rate of ${ }^{14} \mathrm{C}$-carbonate deposition at the edge was not greatly different in shells differing markedly in weight. This may in part be due to the limited range of age of animals available for the studies and in part to the specific nature of growth at the shell edge. The lack of correlation between shell weight and isotope incorporation facilitates the interpretation of isotope data by eliminating excess scatter and unintentional bias due to size of experimental animals.

The observed lower rate of mineral deposition in the evening as compared with midday demonstrates a diurnal control of mineralization by the mantle. The lower rate is correlated with the time of upturning of the mantle and the formation of the daily ridges of the shell (Wrenn, 1972). The protein-to-mineral ratio is 
increased at the time of ridge formation, as shown by protein analysis. The reduction in mineral deposition may result from (1) a decreased supply of calcium due to a decreased mantle circulation when the mantle muscle contracts, causing upturning; (2) a decreased movement of calcium across the mantle; or (3) a decreased secretion of protein participating in crystal nucleation. The increased protein content of the shell ridges reflects a decrease in mineral deposition by the mantle as shown by isotope incorporation and may involve an increase in protein secretion by the mantle as well. A study of the rate of deposition of labelled protein in the shell at various times of day would resolve this and would indicate whether the mantle exerts a diurnal control of protein secretion as well as a diurnal control of mineralization.

The factors inducing the diurnal variation of mineralization in Argopecten are not clear. Short-term lighting does not appear to be a factor since the rates of mineralization in light and darkness at the same time of day were nearly identical. These results are in agreement with those of Dodd (1969), who observed no effect of light on ${ }^{45} \mathrm{Ca}$ deposition in Argopecten and other bivalves. However, the timing of ridge formation in Argopecten has been shown to be influenced by photoperiod (Wrenn, 1972). Tidal variations can scarcely be a controlling factor since ridge formation occurs at about the same time each day (Wrenn, 1972). Control by daily fluctuations in phytoplankton concentrations associated with tidal changes (Kirby-Smith, 1970) to which the experimental animals would have been exposed is unlikely for the same reason. From the evidence available, we support the suggestion of Dodd (1969) that diurnal growth markings may be brought about by an endogenous rhythm. In Argopecten, the rhythm involves a difference in the rate of mineral deposition correlated with an upturning of the mantle during one period of the day.

We thank Dr. Miles A. Crenshaw and Dr. John R. Gregg for their discussion and helpful suggestions in the preparation of the manuscript, and Miss Mayme Lee Blankenship for taking the electron micrograph. A portion of the experimental work was carried out at the Atlantic Estuarine Fisheries Center (National Marine Fisheries Service), Beaufort, North Carolina. We appreciate the help of Dr. T. R. Rice for making space and facilities available. This study was supported in part by grant DE 01382-12 from the National Institute of Dental Research.

\section{SUMMARY}

1. Incorporation of calcium and carbonate into shell has been studied in the scallop Argopecten irradians using ${ }^{45} \mathrm{Ca}$ and ${ }^{14} \mathrm{C}$-bicarbonate.

2. The incorporation of ${ }^{45} \mathrm{Ca}$ and ${ }^{14} \mathrm{C}$-carbonate into shell was linear with time after a lag period of 1 to 2 hours. The shell-forming mantle tissue attained a steady state with respect to ${ }^{45} \mathrm{Ca}$ in the sea water medium within 2 hours.

3. The molar ratio of ${ }^{45} \mathrm{Ca}$ to ${ }^{14} \mathrm{C}$-carbonate deposited in shell was not significantly different from unity during 5 hours.

4. The rate of incorporation of ${ }^{14} \mathrm{C}$-carbonate into shell was highest at the ventral edge and extremely low in the central and hinge areas.

5. The rate of incorporation at the ventral shell edge did not change with increase in shell size. 
6. The rate of incorporation of carbonate was low at night when growth ridges form and increased 3 -fold at midday when growth ridges are not being formed.

7. The protein content of the shell ridges was $32.9 \pm 3.9 \%$ and the protein content of the shell including ridges was $16.0 \pm 2.1 \%$.

\section{LITERATURE CITED}

BrAy, G. A., 1960. A simple efficient liquid scintillator for counting aqueous solutions in a liquid scintillation counter. Anal. Biochem., 1: 279-285.

Brown, F. A., Jr., M. F. Bennett, H. M. Webb, and C. L. Ralph, 1956. Persistent daily, monthly, and 27 day cycles of activity in the oyster and quahog. J. Exp. Zool., 131: $235-262$.

Clark, G. R., II, 1968. Mollusk shell: daily growth lines. Science, 161: 800-802.

Clark, G. R., II, 1974. Calcification on an unstable substrate: marginal growth in the mollusk Pecten diegensis. Science, 183: 968-970.

Crenshaw, M. A., 1972. The inorganic composition of molluscan extrapallial fluid. Biol. Bull., 143: 506-512.

Crenshaw, M. A., And J. M. NefF, 1969. Decalcification at the mantle-shell interface in molluscs. Amer. Zool., 9: 881-885.

Dopd, J. R., 1969. Effect of light on rate of growth of bivalves. Nature, 224: 617-618.

Dugal, L. P., 1939. The use of calcareous shell to buffer the product of anaerobic glycolysis in Venus mercenaria. J. Cell. Comp. Physiol., 13: 235-251.

Hammen, C. S., and K. M. Wilbur, 1959. Carbon dioxide fixation in marine invertebrates. I. The main pathway in the oyster. J. Biol. Chem., 234: 1268-1271.

House, M. R., ANd G. E. FArrow, 1968. Daily growth banding in the shell of the cockle, Cardium edule. Nature, 219: 1384-1386.

Jodrey, L. H., 1953. Studies on shell formation. III. Measurement of calcium deposition in shell and calcium turnover in mantle tissue using the mantle-shell preparation and $\mathrm{Ca}^{45}$. Biol. Bull., 104 : 398-407.

Kado, Y., 1960. Studies on shell formation in mollusca. J. Sci. Hiroshima Univ., Ser B, 19: $163-210$.

Kirby-Smith, W. W., 1970. Growth of the scallops, Argopecten irradians concentricus (Say) and Argopecten gibbus (Linné), as influenced by food and temperature. Ph.D. dissertation, Duke University, 127 pp.

Rhoads, D. C., And G. PAnnella, 1970. The use of molluscan shell growth patterns in ecology and paleoecology. Lethaia, 3: 143-161.

Sandeen, S. I., G. C. Stephens, And F. A. Brown, Jr., 1954. Persistent daily and tidal rhythms of oxygen consumption in two species of marine snails. Physiol. Zool., 27: $350-356$.

Speeg, K. V., Jr., and J. W. Campbell, 1968. Formation and volatilization of ammonia gas by terrestrial snails. Am. J. Physiol., 214: 1392-1402.

Wilbur, K. M., 1972. Shell formation in mollusks. Pages 243-282 in M. Florkin and B. T. Scheer, Eds., Chemical Zoology, V ol. VII. Academic Press, New York.

Wilbur, K. M., And L. H. Jodrey, 1952. Studies on shell formation. I. Measurement of the rate of shell formation using $\mathrm{Ca}^{45}$. Biol. Bull., 103: 269-276.

Wilbur, K. M., And L. H. Jodrey, 1955. Studies on shell formation. IV. The respiratory metabolism of the oyster mantle. Biol. Bull., 108: 346-358.

Wilbur, K. M., And K. Simkiss, 1968. Calcified shells. Pages 229-295 in M. Florkin and E. H. Stotz, Eds., Comprehensive Biochemistry, Vol. 26A. Elsevier Publishing Co., Amsterdam.

Wrenn, S. L., 1972. Daily increment formation and synchronization in the bay scallop. American Society of Zoologists Summer Meeting, Division of Comparative Physiology and Biochemistry with the American Physiological Society, Amer. Zool., 12: xxxvii.

Wright, D. G. S., 1971. Aspects of respiration of the fresh water snail Lymnae pallustris (Müller). Can. J. Zool., 49: 997-1000.

Zischke, J. A., N. Watabe, And K. M. Wilbur, 1970. Studies on shell formation: measurement of growth in the gastropod Ampullarius glaucus. Malacologia, 10: 423-439. 


\section{$2 \mathrm{BHL}$ Biodiversity Heritage Library}

Wheeler, Alfred P, Blackwelder, Patricia L, and Wilbur, Karl M. 1975. "SHELL GROWTH IN THE SCALLOP ARGOPECTEN IRRADIANS. I. ISOTOPE INCORPORATION WITH REFERENCE TO DIURNAL GROWTH." The Biological bulletin 148, 472-482. https://doi.org/10.2307/1540523.

View This Item Online: https://www.biodiversitylibrary.org/item/17347

DOI: https://doi.org/10.2307/1540523

Permalink: https://www.biodiversitylibrary.org/partpdf/33468

\section{Holding Institution}

MBLWHOI Library

\section{Sponsored by}

MBLWHOI Library

\section{Copyright \& Reuse}

Copyright Status: In copyright. Digitized with the permission of the rights holder.

License: http://creativecommons.org/licenses/by-nc-sa/3.0/

Rights: https://biodiversitylibrary.org/permissions

This document was created from content at the Biodiversity Heritage Library, the world's largest open access digital library for biodiversity literature and archives. Visit BHL at https://www.biodiversitylibrary.org. 